УДК 81'22:81'42

DOI https://doi.org/10.26661/2414-9594-2020-2-2

\title{
КОМПОЗИЦІЙНИЙ І ФОРМАЛЬНИЙ РІВНІ КОГЕЗІЇ В АНГЛІЙСЬКОМОВНИХ ТЕКСТАХ ТЕНДЕРНОЇ ДОКУМЕНТАЦІЇ
}

\author{
Борковська І. П. \\ кандидат філологічних наук, \\ дочент кафедри англійської мови гуманітарного спрямування № 3 \\ Національний технічний університет Украӥни \\ «Київський політехнічний інститут імені Ігоря Сікорського» \\ пр. Перемоги, 37, Київ, Украӥна \\ orcid.org/0000-0001-5035-7866 \\ Borkovskaya@meta.ua \\ Карачун Ю. Г. \\ кандидат філологічних наук, \\ старший викладач кафедри теорії, практики та перекладу англійської мови \\ Національний технічний університет Украӥни \\ «Київський політехнічний інститут імені Ігоря Сікорського» \\ пр. Перемоги, 37, Київ, Украӥна \\ orcid.org/0000-0002-5171-8704 \\ juliakarachun@ukr.net
}

Ключові слова: ділові тексти, категорія когезіі, тендерний документ, мовні засоби, композиційна зв'язність, сполучники.
Статтю присвячено опису категорії когезії в ділових текстах англійської мови. На прикладі текстів тендерної документації виявлено текстоутворювальну роль цієї категорії. Визначено, що в основі когезії знаходяться граматичні взаємовідношення. Завдяки лінгвістичному характеру категорії зв’язності, що проявляється на різних мовних рівнях, виокремлюють такі види зв'язності: лексико-граматичні і функційно-синтаксичні засоби когезіі.

Вибір засобів когезії визначено специфікою стилю. Представлено трактування когезії ділових текстів як структурної організації окремих блоків тексту за допомогою лексико-граматичних зв'язків.

Виокремлено два рівні когезії: композиційний та формальний. 3'ясовано, що когезіальна зв'язність на композиційному рівні акцентується у розташуванні двох блоків тексту з чітким розташуванням структурних частин. Перший блок містить вступ "Рreface", а наступний блок, своєю чергою, складається 3 трьох розділів. Підкреслюється важливість композиційної когезії у формуванні зв’язності ділового тексту.

Проведено аналіз формального складника ділового тексту в такому напрямі: виявлено традиційні функційно-синтаксичні засоби когезії, серед яких виокремлено сполучники (сурядні, підрядні та парні) і сполучникові слова.

Обгрунтовано вживання відповідних сполучних засобів у тендерній документації як жанру ділової кореспонденції, які легко ідентифікувати без контексту або певних лексичних маркерів, підкреслено важливість однозначності таких сполучних засобів у жанрах ділових текстів.

Представлено розгорнутий список сурядних та підрядних сполучників, які засвідчують досліджувані тендерні документи. Визначено роль сурядних сполучників у нанизуванні фрагментів інформації, що допомагає пов'язати текст і забезпечує ритмічність ділового мовлення. Проаналізовано підсилювальну роль підрядних сполучників та їх значення для зв'язку від попередньої до нової ідеї у документації.

Можна спостерігати системний характер використання когезійних мовних засобів, серед яких сполучники відіграють суттєву роль в автоматизації вибору слів і характеру їх вживання. 


\title{
COMPOSITIONAL AND FORMAL LEVELS OF COHESION IN ENGLISH TEXTS OF TENDER DOCUMENTATION
}

\author{
Borkovska I. P. \\ Candidate of Philological Sciences, \\ Associate Professor at the Department of English for Humanities No. 3 \\ National Technical University of Ukraine "Igor Sikorsky Kyiv Polytechnic Institute" \\ Peremohy ave., 37, Kyiv, Ukraine \\ orcid.org/0000-0001-5035-7866 \\ Borkovskaya@meta.ua
}

\author{
Karachun Yu. G. \\ Candidate of Philological Sciences, \\ Associate Professor of the Department of Theory, Practice and Translation of English Language \\ National Technical University of Ukraine "Igor Sikorsky Kyiv Polytechnic Institute" \\ Peremohy ave., 37, Kyiv, Ukraine \\ orcid.org/0000-0002-5171-8704 \\ juliakarachun@ukr.net
}

Key words: business texts, cohesion category, tender document, language means, compositional cohesion; conjunctions.
The article is devoted to the description of the category of cohesion in the business texts of the English language. The text-forming role of this category is revealed on the example of texts of the tender documentation. Due to the linguistic nature of the category of coherence, which is manifested at different linguistic levels, there are different types of coherence, among which are generally accepted classifications by linguistic means, namely: lexical and grammatical means and functional-syntactic means of cohesion. The choice of means of cohesion is determined by the specifics of the style. It has been presented the interpretation of the cohesion of business texts as a structural organization of individual blocks of the text with the help of lexical and grammatical connections.

There are two levels of cohesion: compositional and formal. It has been found that cohesive coherence at the compositional level is emphasized in the arrangement of two blocks of text with a clear arrangement of structural parts. The first block contains the introduction "Preface", and the next block, in turn, consists of three sections. It has been emphasized the importance of compositional cohesion in the formation of the text.

The analysis of the formal component in the business text has been carried out. Traditional functional-syntactic means of cohesion have been revealed, among which conjunctions and conjunctive words.

An extensive list of conjunctive and subjunctive conjunctions that certify the tender documents has been presented. It has been highlighted the role of conjunctions in the forming of the text, connecting pieces of the information and setting the rhythm of business speech.

The systemic nature of the use of cohesive language tools has been observed, among which conjunctions play a significant role in automating of the words choice. 
Постановка проблеми. Текст $є$ об'єктом дослідження науковців різних сфер і це зумовлює існування різних поглядів щодо його функцій та категорій. У наші дні відбувається активна експансія ділового тексту у формі контрактів, ділових листів і тендерних документів у всі сфери життя. Тендерна документація є одним зі способів торгів, під час яких підписується важливий контракт між стороною на отримання послуг і їх виконавцем, та відіграє значну роль у разі визначення переможця торгів. Тому розгляд особливостей тексту, зокрема тексту тендерної документації, постає досить актуальним. До найголовніших ознак тексту належать когезія (зв'язність) і когерентність (цілісність). Саме когезія виступає головною передумовою успішної комунікації тексту, а як відомо, у діловій сфері велику роль відіграє писемна комунікація між партнерами. Проблема текстових категорій, зокрема когезії, в ділових текстах ще до кінця не вирішена. Від іiі розв'язання залежить подальший розвиток розуміння ділових текстів різних жанрів та їх призначення.

Аналіз наукових досліджень, на які спирасться автор. Визначальне місце когезії у низці текстових категорій зумовило значний інтерес до неї вітчизняних і зарубіжних науковців, серед яких - I. Гальперін, В. Павленко, М. Карп, М.А.К. Халлідей, Р. Хассан та інші, і розширило термінологічні аспекти самого поняття когезії.

Формулювання мети та завдань статті. Об'єктом дослідження є тексти тендерної документації, предметом - структурно-композиційна, або когезіальна організація зазначених текстів, що проявляється у структурному розташуванні певних частин тексту, та формальні засоби вираження зв'язності, засоби зчеплення, що функціюють у текстах тендерної документації.

Метою цієї статті $\epsilon$ розгляд категорії когезії на композиційному і формальному рівнях в англійськомовних текстах тендерної документації.

Відповідно до мети визначено такі завдання розглянути та проаналізувати наявні точки зору, що стосуються такої проблеми; обгрунтувати важливість композиційної зв'язності; дослідити регулярні засоби функційно-синтаксичної когезії у текстах тендерної документації, а саме сполучники (сурядні, підрядні та парні) і сполучникові слова.

Виклад основного матеріалу 3 обгрунтуванням отриманих результатів. Характеризуючи когезію як структурно-текстоутворювальну категорію, І. Гальперін відзначає ії глобальність у межах цілого тексту і вказує на важливість дослідження компонентів тексту. Когезія виникає у процесі розгортання тексту і відбирає мовні засоби для взаємодії елементів тексту [3, с. 125].

Когезію трактують як властивість, яка відіграє важливу роль у визначенні того, що перед нами не просто набір висловлювань, а саме текст як структурно-семантична єдність, об'єднана комунікативною цілісністю, смисловою завершеністю, з логічними, граматичними і семантичними зв'язками. Цим можна пояснити, чому багаточисельні визначення тексту базуються на зазначеній категорії.

Критерій когезії характеризує спосіб утворення поверхневої структури тексту. Важливим $€$ те, що когезія демонструє, яким чином співвідносяться слова в тексті за допомогою граматичних форм та відношень і тому можна стверджувати, що в основі когезії лежать граматичні взаємовідношення. Поряд із цим когезію трактують як зчеплення елементів (слів) тексту, що не тільки слідують один за одним, але й віддалених один від одного у межах тексту [1, с. 13-15]. До такої думки приєднується і О. Зайцева, яка називає когезію основним діючим механізмом, який оптимально узгоджує відносини всіх фрагментів тексту [4, с. 15-19].

Лінгвістичний характер категорії зв'язності та її прояви на різних мовних рівнях дозволяють виділити види зв'язності. Так, М.А.К. Хеллідей i Р. Хасан виокремлюють такі види когезії, як: лексична, граматична (референція, субституция, еліпсіс) і з'єднання, яке дослідники відносять до перехідних випадків [8, с. 126].

В. Лукін акцентує увагу на п'яти типах зв'язності: 1) зв'язність типових образів, до яких він відніс лінії і крапки, які відіграють роль у створенні тексту завдяки своїй послідовності; 2) зв'язність знакових елементів тексту, серед яких $\epsilon$ не тільки слова, а й лапки та курсив; 3) лексична зв'язність як на рівні займенників і прислівників, які вказують на референт, так і на рівні умовних знаків, до яких належать слова і частини слів; 4) семантико-синтаксична зв'язність, що ураховує явища пресупозиції, імплікації, еліпсис і актуальне членування; 5) граматична зв'язність, що включає повтори граматичних форм [6, с. 21-22].

В. Павленко диференціює когезію за мовними засобами, такі як лексико-граматичні засоби i функційно-синтаксичні засоби когезії. До перших віднесено іменники, всі види займенників, прислівники 3 просторовим і часовим значеннями; до функційно-синтаксичних засобів зараховані спеціальні конструкції зв'язку, вступні слова, анафоричні сурядні сполучники і логічні прислівники [7, c. 140].

Як відомо, композиція більшості жанрів ділових текстів носить тричастинний характер послідовність трьох частин інформації, які часто називають інформаційними блоками: вступний, основний та заключний.

Однак у текстах тендерної документації на композиційному рівні когезіальна зв'язність базується на розташуванні двох блоків тексту, 
причому проведений аналіз показав, що в тендерній документації завжди зберігається чітке розташування цих структурних частин.

Відповідно до сказаного вище ми трактуємо когезію ділових текстів як структурну організацію окремих блоків тексту за допомогою лексико-граматичних зв'язків і у найбільш загальному вигляді виокремлюємо два рівні когезії: композиційний і формальний.

Дослідження 10 тендерних документів, що належать до різних сфер виробництва, дозволяє зробити висновок, що у всіх тендерах виділяється вступ "Рreface”, перший розділ «Тендер», другий розділ «Контракт» і третій розділ «Роботи», тобто спостерігається композиція, яка містить два компоненти - вступ і основну частину.

У вступі "Рreface" висвітлюється інформація про компанію, що надала тендерний документ, який буде представлено на відкритих тендерних торгах. У цьому блоці тендера представлені чіткі інструкції, як заповнити розділи тендерної документації.

Перший розділ «Тендер» складається 3 декількох реквізитів і включає важливу інформацію, яка є необхідною для підготовки документів, щоб стати учасниками тендера. Тут подається інформація про відкриття тендера та укладання контракту. У першому розділі також вносяться положення, які пов'язані із закупівлею, висуваються вимоги до роботодавця, цін та валюти тендера.

Другий розділ “Тhe Contract” містить умови контракту, серед яких є контроль тривалості контракту та оплати. Як і в будь якому контракті, тут є інформація щодо домовленості про суму збитків, що підлягають сплаті постраждалій стороні.

У третьому розділі "The Works" надається інформація про оцінки виконуваних робіт. Деякі підрозділи містять графіки з описом складності та цін запланованих робіт.

Отже, композиційна зв'язність акцентується на чіткій будові ділового тексту та розміщенні його частин. Така композиційна особливість тендерного документа $є$ когезуючим засобом, адже вона пов'язує всі часові і просторові описи, що містяться в тендерній документації зі сторонами контракту.

Робота в межах нашого дослідження показала необхідність проведення аналізу формального складника тексту в такому напрямі - виявити імпліцитно невиражену інформацію через дослідження когезіальної зв'язності. На формальному рівні засоби когезії ділових текстів прокласифіковано за способом оформлення зв'язності на два типи: лексико-граматичні засоби і функційно-синтаксичні засоби когезії. До лексико-граматичних засобів ми віднесли іменники, займенники: особові, присвійні, вказівні та ін.; прислівники 3 просторовим і тимчасовим значеннями.
Основна відмінність функційно-синтаксичних засобів від лексико-граматичних засобів полягає в тому, що вони не співвідносяться 3 лексичною стороною пропозиції і виконують тільки синтаксичну функцію.

У цій роботі ми аналізуємо саме функційно-синтаксичний простір когезіі. Отже, для того щоб текст не втратив зв'язності, відправник ділового тексту використовує традиційні мовні засоби і одним із регулярних засобів функційно-синтаксичної когезії у ділових текстах виступають сполучники (сурядні, підрядні та парні) i сполучникові слова. Такий спосіб когезії називають ще сполучуваністю, що означає з'єднання елементів тексту за допомогою сполучників, конекторів і цілих речень [5, с. 184].

Сполучник відіграє важливу роль в об'єднанні елементів інформації та створенні їі цілісності. До того ж за допомогою нього визначається залежність або незалежність відносин відповідних частин речення. Тим самим сполучник забезпечує чітку роль кожного з елементів у формуванні інформації [2, с. 79].

У тендерній документації як жанру ділової кореспонденції функціюють тільки ті сполучні засоби, які чітко акцентують синтаксичні категорії сурядності чи підрядності. Такі сполучники легко ідентифікувати навіть без контексту або певних лексичних маркерів, вони не бувають багатозначними у такому типі текстів.

Сурядні сполучники, оформлюючи зв'язок між рівноправними частинами в складносурядне речення, акцентують різні типи синтаксичних відношень (єднальні, розділові, протиставні).

Передусім мова ділових текстів продукує єднальний сурядний сполучникик and, який зазвичай виражає значення єднання: If a tender is not substantially responsive, it will be rejected by the Employer, and may not subsequently be rendered responsive by correction or withdrawal of the nonconformity $[9$, c. 26$]$.

У текстах тендерної документації за допомогою сполучника and часто можна спостерігати випадки передавання вичерпності низки однорідних членів речення: $A$ substantially responsive tender is one which conforms to all terms, conditions, and specifications of the tender documents without material deviation or reservation [9, c. 25].

Характерними для тендерної документації $\epsilon$ структури 3 кількома групами однорідних членів з єднальним сполучником and: A tenderer may be required by the Employer to clarify its foreign currency requirements and to substantiate that the amounts included in the prices, and shown in the Price Schedules, are reasonable and responsive to paragraph $12.1 \ldots[9$, c. 20$]$. 
Наступна виокремлена група сурядних сполучників - протиставні сполучники, які переважно представлені but: Should a subcontractor be determined to be unacceptable, the tender will not be rejected, but the tenderer will be required to substitute an acceptable subcontractor without any change to the tender price [9, с. 24].

Досліджуючи список розділових сурядних сполучників, виявлено, що найактивнішим сполучником є сполучник or, функція якого - виділення одного із двох однорядних членів у реченні: If the Project Manager asks the Contractor to remove a person who is a member of the Contractor's staff or work force [9, c. 57].

У мові ділових текстів сполучник or часто вживають як повторюваний:

All pages of the tender where entries or amendments have been made shall be initialled by the person or persons signing the tender [9, c. 22].

Подекуди в текстах тендерної документації поряд уживаються два сполучники, один 3 яких $\epsilon$ єднальним, а другий - розділовим. Звичайно, у цьому разі кожний вид сполучника надає інформації додаткової семантики: The Employer may require the tenderer to provide any clarification and/or substantiation to determine responsiveness pursuant to paragraph... [9, с. 26].

Слід зазначити, що саме сурядні сполучники виконують роль нанизування фрагментів інформації i це допомагає пов'язати текст і забезпечує ритмічність ділового мовлення.

Підрядні сполучники, як відомо, вказують на відносини між підрядною й головною частиною. Ту ж саму роль виконують і сполучні слова 3 властивостями як самостійних, так і службових частин мови.

Серед підрядних об'єктних сполучників у текстах тендерів найпродуктивніше вживають сполучники that i which, які сприяють смисловій зв'язності тендерного документа. Вони узгоджуються з іменником і вживаються для приєднання підрядної частини до головної, розкриваючи значення ключового слова:

1. At the same time that the Employer notifies the successful tenderer that its tender has been accepted, the Employer will send the tenderer the Agreement.

2. ...it may be extended by the Employer, notice of which extension(s) to the Bank is hereby waived $[9$, c. 43$]$.

У наступному прикладі прослідковуємо використання об'єктного сполучника, що розкриває значення двох, а інколи і більше однорідних слів: The risk of personal injury, death, or loss of or damage to property (excluding the Works, Plant, Materials, and Equipment), which are due to... [9, c. 58].

3-поміж умовних сполучників підрядності найпродуктивніше використовують сполучник if $\mathrm{i}$ значно менше unless:
1. If required in the Tender Data, he tenderer shall furnish, as part of its tender, a Tender Security in the amount specified therein [9, c. 21].

2. Unless specified otherwise in the Tender Data, tenders will be evaluated as quoted in the currency of the tender specified in paragraph $12 \ldots$ [9, c. 26].

Набір парних сполучників, як свідчить наше дослідження, типовий для ділових текстів (both ... and, not only...but, either... or):

1. If the Employer accepts these proposals, the Intended Completion Date will be adjusted accordingly and confirmed by both the Employer and the Contractor.

2. This will not only be necessary to fulfill the

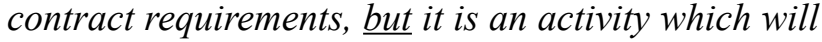
provide him with the information.

3. Sanction a firm or individual, including declaring them ineligible, either indefinitely or for a stated period of time [9, с. 62].

Підсилювальні й протиставні відношення виражаються переважно за допомогою сполучникових прислівників. Необхідно відзначити, що для мови документів особливо характерне використання сполучникового підсилювального прислівника also: Under the terms of the contract, the Contractor will also be responsible for the continuous monitoring and control of road [9, c. 26].

Для протиставлення і, відповідно, зв'язку двох речень часто використовується сполучниковий прислівник however, який сполучає два незалежні речення в одне складносурядне. Він також часто стоїть на початку речення для логічного зв'язку 3 попереднім реченням. Цей прислівник разом 3 neverthless, nonetheless також виконує підсилювальну роль у протиставленні: However, it may be the future generations who will perhaps benefit most, since they will not have to pay for the reconstruction of roads destroyed because of a lack of maintenance today...[9, c. 62].

Для логічного переходу до подачі нової інформації, для зв'язку від попередньої до нової ідеї у документації часто вживається therefore, consequently, furthermore:

1. Consequently, a well-designed prequalification process is highly recommended in order to ensure that only qualified bidders participate in the bidding process....[9, c. 26].

2. Furthermore, Bidders shall be aware of the provision stated in Sub-Clause 15.6 of the Particular Conditions [9, c. 24].

Висновки, рекомендації, перспективи подальших досліджень. Як бачимо, в англійськомовних текстах тендерної документації, як i в інших документах, спостерігається системний характер використання когезійних мовних 
засобів, серед яких сполучники відіграють суттєву роль в автоматизації вибору слів і характеру їх вживання. Речення будуються за певними моделями, у яких $є$ конструкції із сурядними i підрядними сполучниками та сполучними словами. Домінування використання тих чи інших когезійних засобів та інших особливостей вживання засобів мови, вживання різних способів зв'язку між частинами висловлювання відповідає офіційно-діловому стилю.

Такі висновки спонукають нас розширити джерельну базу дослідження для грунтовнішого аналізу сполучникової системи жанрів ділової кореспонденції, що дало би змогу глибше вивчити питання про функції засобів зв'язку в англійськомовному діловому тексті.

\section{ЛІТЕРАТУРА}

1. Атултанова В.Б. Связность текста как переводческая проблема : дис. ... канд. филол наук : 10.02.04. Москва : МГЛУ, 2006. 234 с.

2. Білоусова О.І. Сполучники та сполучні слова як важливі компоненти законодавчого тексту. Український смисл. 2017. № 2017. С. 178-189.

3. Гальперин. И.Р. Текст как объект лингвистического исследования. Москва : Наука, 1981. С. 125.

4. Зайцева О.Л. Когезия в текстах газетных и журнальных статей. Университетские чтения-2015 : материалы научно-методических чтений. ПГЛУ. Пятигорск : Изд-во ПГЛУ, 2015. С. 15-19.

5. Карп М. Когезія та когерентність як сукупність текстового зв'язку у британських художніх мультимодальних творах. Мова і культура. 2014. Вип. 17, т. 2. С. 182-189.

6. Лукин В.А. Художественный текст: Основы лингвистической теории. Аналитический минимум. Москва : Изд-во «Ось-89», 2005. 560 с.

7. Павленко В.Г. Категория когезии в текстах научно-педагогической публицистики английского языка. Филологические науки. Вопросы теории и практики : науч.-теорет. и прикладной журн. 2016. № 4, ч. 2. С. 139-142.

8. Halliday M.A.K., Hasan R. Language, Context and Text: A Social Semiotic Perspective. Oxford : Oxford Univ. Press, 1989. 126 p.

9. Tender documentation. URL: http://kamgs3.kpi.ua/sites/default/files/1\%20EBRR_tender $\% 201 \% 20 \% 20$ procedure.pdf.

\section{REFERENCES}

1. Atultanova, V.B. (2006). Sviaznost teksta kak perevodcheskaia problema [Connectivity of the text as a translation problem]: Extended abstract of Candidate's thesis (Philolgy). Moscow [in Russian].

2. Bilousova, O.I. (2017). Spoluchnyky ta spoluchni slova yak vazhlyvi komponenty zakonodavchoho tekstu [Conjunctions and connecting words as important components of the legislative text]. Ukrainskyi smysl [Ukrainian meaning], 178-189 [in Ukrainian].

3. Halperyn, Y.R. (1981). Tekst kak ob'ekt lynhvystycheskoho yssledovanyia [Text as an object of linguistic research]. Moskva: Nauka [in Russian].

4. Zaitseva, O.L. (2015). Kohezyia $\mathrm{v}$ tekstakh hazetnyikh y zhurnalnyikh statei [Cohesion in the texts of newspaper and magazine articles]. Unyversytetskye chtenyia-2015: materyalyi nauchno-metodycheskykh chtenyi [University readings-2015: materials of scientific-methodical readings], 15-19 [in Russian].

5. Karp, M. (2014). Koheziia ta koherentnist yak sukupnist tekstovoho zviazku u brytanskykh khudozhnikh multymodalnykh tvorakh [Cohesion and coherence as a set of textual connections in British multimodal works of art]. Mova i kultura. [Language and culture]. No. 17, 182-189 [in Ukrainian].

6. Lukyn, V.A. (2005). Khudozhestvennyi tekst: Osnovyi lynhvystycheskoi teoryy [Fictional text: Fundamentals of linguistic theory]. Analytycheskyi mynymum [Analytical minimum]. Moskva : Os-8 [in Russian].

7. Pavlenko, V.H. (2016). Katehoryia kohezyy $\mathrm{v}$ tekstakh nauchno-pedahohycheskoi publytsystyky anhlyiskoho yazyika [The category of cohesion in the texts of scientific and pedagogical journalism of the English language]. Nauch.-teoret. and applied journal. Fylolohycheskye nauky. Voprosyi teoryy y praktyky [Philological sciences. Questions of theory and practice], No. 4, 139-142 [in Russian].

8. Halliday, M.A.K., Hasan, R. (1989). Language, Context and Text: A Social Semiotic Perspective. Oxford: Oxford Univ. Press, 1989. 126 p. [in English].

9. Tender documentation. URL: http://kamgs3.kpi.ua/sites/default/files/1\%20EBRR_tender $\% 201 \% 20 \% 20$ procedure.pdf [in English]. 